\title{
Regulatory Compliance and Air Quality Permitting: Why Do Firms Overcomply?
}

\author{
Leisha DeHart-Davis and Barry Bozeman \\ Georgia Tech
}

This research was supported by the U.S. Environmental Protection Agency under grant \#R824753. The findings are solely the authors' and do not necessarily represent those of the U.S. EPA.

\footnotetext{
The authors wish to acknowledge the valuable input of four anonymous referees.
}

J-PART 11(2001):4:471-508

\begin{abstract}
Industry overcompliance with pollution standards has puzzled economists, leading to a variety of hypotheses about the objectives companies expect to achieve by doing so. This article examines the possibility of overcompliance with a different type of environmental regulation: the paperwork requirements for completing a federal Title $V$ air operating permit application. We suggest that unique political circumstances set the stage for companies to overcomply with their Title $V$ permit application requirements, including tremendous regulatory uncertainty, stiff penalties for intentional corporate noncompliance, and consultants who allegedly were eager to capitalize on both circumstances to sell their services. This regulatory context led us to hypothesize that corporate Title V overcompliance was driven by four factors: a complying organization's internal control processes and red tape; its permitting experience; the quality and quantity of contact with state regulators; and whether the company subcontracted its compliance-related activities. To test the influence of these factors, we analyzed survey data from more than five hundred companies in four states. The results indicate that, while internal red tape and permit inexperience were insignificant cost influences, both the increased contact with regulators and the use of consultants corresponded with higher Title $V$ costs and, by extension, the probability of overcompliance. In contrast to expectations, the presence of regulated facilities in other states was associated with significantly higher Title $V$ costs, perhaps due to inflationary effects of cross-state permit coordination. While caution is warranted in interpretation, the results spark the possibility that communicating extensively with regulators and subcontracting compliance tasks-particularly under conditions of regulatory uncertainty and high perceived noncompliance risks-may lead companies to overly expansive compliance with permit processes.
\end{abstract}

471/Journal of Public Administration Research and Theory 
In the environmental economics literature, overcompliance typically is measured by the cost differential between the minimal pollution control strategies that are required by law and those that are implemented by industrial firms (McClelland and Horowitz 1999). Economists have been surprised by the tendency of some companies to spend more money and to commit more resources than are required to comply with environmental regulations. This phenomenon has stimulated a range of hypotheses on the objectives of overcompliance-enhancing public image, increasing competitive advantage, and preparing for future regulatory requirements.

The very notion of overcompliance may well strike some as bizarre. One might ask, Just how is it possible to overcomply with environmental regulations? Since reducing pollution is in the public interest, a company that chooses to exceed environmental requirements is perhaps best viewed as a good corporate citizen rather than as an overcomplying and, at least by implication, inefficient firm. While this point certainly has some merit, the issue is generally more complicated. In some instances (including the policy we examine here), exceeding environmental regulatory requirements does not necessarily have a direct effect on pollution abatement. Furthermore, if companies overcomply there is always the possibility that the excess resources could have been put to better use, either by the company itself or for some alternative pollution abatement activity (e.g., purchasing pollution control equipment). Moreover, we cannot in this article take a clear stand on the public interest implications, positive or negative, of overcompliance. But information about the degree and causes of overcompliance may prove useful to both regulators and the regulated community.

In order to test hypotheses about overcompliance, we examine corporate compliance with Title V of the 1990 Clean Air Act Amendments. The legislation requires firms to document their emission sources, pollution control equipment, and applicable regulations in a single operating permit. The legislation has teeth, including most particularly a penalty for providing false or misleading information coupled with criminal liability for the highest corporate official in offending companies. With gallows humor, this has come to be known as the designated felon provision. Industrial compliance with Title $\mathrm{V}$ requirements is complicated by the timing of regulatory implementation in the mid1990 s, when the nation was debating the value of regulation. The funding of the U.S. Environmental Protection Agency (EPA), the implementing federal agency, was jeopardized. This turbulence led EPA to backslide on Title $V$ compliance requirements as a matter of political survival, which in turn fostered uncertainty at 
the state regulatory level as to the exact nature of the Title $\mathrm{V}$ requirements. In this context, we employ questionnaire-based data from more than five hundred Title V-regulated firms in four states. We expect that four factors will influence overcompliance: a complying organization's internal control processes and red tape; its degree of general permit experience; its level of interpersonal contact with state and federal regulators; and whether the company subcontracted its compliance-related activities. Specifically, we expect that companies with a higher level of internal control and red tape will be more risk averse and, consequently, more likely to overcomply with the Title V permitting regulations. We hypothesize that companies with a higher level of permitting experience will be less likely to overcomply, because of their familiarity with regulatory compliance and lesser initial costs of information. By contrast, we anticipate that companies with higher levels of interpersonal contact with state regulators will tend to overcomply because they are negotiating more, possibly ambiguous, information. Finally, we expect that companies that subcontract their compliance requirements will overcomply because contractors have incentives (e.g., billable hours) to do more than legally is required on their clients' behalf.

Before explicating further and testing our hypotheses, it will be useful to provide some additional information about the history of Title $\mathrm{V}$ permitting. We will also provide information about the research project from which this study emerged.

\section{PATHWAY TO A NATIONAL PERMIT SYSTEM}

Title V of the 1990 Clean Air Act Amendments significantly changed the way states conducted a key aspect of enforcing air pollution control regulations: the matter of industrial operating permits. Such permits are traditionally designed to enable a state to enforce industrial air quality regulations by detailing the terms of company compliance. However, before 1990 states varied widely in program design, permit content, and enforcement levels. Many lacked operating permit programs, requiring paperwork only for construction or modification of pollutionemitting processes. Others, such as Wisconsin, attempted to devise operating permit programs that ultimately were underfunded and unenforced. In states that did have operating permit programs, such as Louisiana and Oregon, the programs often differed significantly from those that would be ultimately required by Title V. Only a handful of states, such as California, had operating permit programs that were similar to the scope of Title V. 
Without a central document specifying firm-level compliance requirements, it was difficult for companies to determine the air quality regulations to which they were subject. ${ }^{1}$ The only source of this information-the state implementation plan (SIP) which maps out how a state will achieve federal air quality standardswas typically inaccessible and complex, burying applicable requirements in hundreds of pages of regulatory detail that states rarely distributed. The difficulties in determining a company's applicable requirements from the SIP contributed to the proliferation of compliance agreements negotiated by sources, the state, and EPA, which sometimes served to revise state plans (Landy, Roberts, and Thomas 1994, 205). This pattern was particularly common before 1977, when the nation faced economic recession and regulatory compliance was the last issue important to state governments.

Thus confusion and ambiguity over standards, negotiated compliance agreements between industry and regulators, and lack of states' political will to pursue aggressive enforcement led Congress-with the strong support of EPA and the first Bush administration-to include in the 1990 CAAA the highly detailed Title $\mathrm{V}$ legislation for state operating permit programs. While much of the language in Title $\mathrm{V}$ outlines minimal requirements for establishing and enforcing operating permit programs, the legislation also addresses permitted companies directly through requirements for permit application content, monitoring, and record keeping. The regulatory hammer for corporate Title $\mathrm{V}$ compliance comes from Title I of the 1990 Clean Air Act Amendments: the so-called designated felon clause. This section of the statute addressing enforceability of the entire Act empowers the federal government to hold the highest corporate official criminally liable for misleading or false information provided in the permit application (42 U.S.C. 7412). The clause seeks to capture the attention of corporate executives in a regulatory arena where compliance is perceived ancillary to operations (Heyes 1998).

'According to a lawyer with EPA's Office of General Counsel: "You might think it reasonable to assume that sources know their compliance requirements, but they just don't. Many sources have never had a reason to take a comprehensive look at their emissions. Those that did take that look were frustrated by having to go through dozens of notebooks (the SIP)." Interview with anonymous official, April 1996.

\section{THE ROCKY ROAD FROM LEGISLATION TO REGULATION}

Title $\mathrm{V}$ was a blunt instrument designed to mold recalcitrant states and crafty companies into regulatory compliance. Given the breadth of its reach-from economic sanctions against states to criminal liability of chief operating officers-it should come as no surprise that many were fearful of its ramifications. In the prelegislative discourse, state and local regulators voiced opposition to EPA review and veto (Bryner 1995, 180), a fear that went 
unheeded. Their opposition intensified after EPA issued the final Part 70 regulations that specified even further the program requirements to which states were subject. ${ }^{2}$ As of 1995 , the states, industry, and environmental groups had sued EPA over nearly sixty parts of the final rules (Novello, Hoffnagle, McCutchen, and Weiss 1995, 1).

EPA responded to this turbulence in two ways. First, the agency reproposed the most controversial aspects of the final rules, which deal with operational flexibility ${ }^{3}$ at facilities. Second, the agency released two white papers, nonbinding and nonregulatory guidance documents that increase the flexibility with which states implement their operating permit program requirements (USEPA 1995a and 1995b). These responses were also driven by the political drama playing out in Congress during the height of Title V implementation, when Republicans won a majority of seats in the Senate and House and a majority of the nation's governorships in the November 1994 elections. With the first Republican dominated Congress in forty years and the first Republican majority of governorships since 1972, the new Republican majority focused on a range of legislative initiatives to reduce general regulatory burden and federal discretion.

Title $\mathrm{V}$ became the target of reform in two draft bills that sought to limit EPA's power over states in permit program design and to give companies production flexibility in permitting. Senator Lauch Faircloth (R-NC), chairman of the Senate Environment and Public Works Committee subcommittee on clean air, drafted the Clean Air Simplification and Efficiency Act of 1995. The draft bill would have required state Title V programs to be acceptable prima facie to EPA, thus eliminating the need for a possible EPA takeover in the event that an acceptable

${ }^{2}$ While it is technically correct to refer to these new operating permits by their regulatory origins, Part 70 , it is the vernacular of the regulatory and regulated communities to refer to them as Title $\mathrm{V}$ permits, as we will do throughout the remainder of this article.

\footnotetext{
${ }^{3}$ Operational flexibility describes the degree to which companies can make operational changes at a facility without noting those changes in revisions to their air emissions permits. The greater a permit's operational flexibility, the more changes can be made without a permit revision.
} program was not designed. The bill would have limited EPA's ability to require review and approval before businesses made changes to processes or products, and it would also have limited sanctions to recalcitrant states, not just those working in good faith with EPA. Representative Joe Barton (R-TX) unsuccessfully proposed a broader range of technical changes in a draft bill that called for simultaneous operating permit revisions and process changes along with shorter delays for sources increasing production or revising manufacturing processes. Had these bills been passed into law, they would have required alterations in some Title $\mathrm{V}$ programs that had already been authorized by state legislatures, submitted to EPA for review and approval, and partly implemented by state air quality agencies. 


\section{HYPOTHETICAL DETERMINANTS OF TITLE V OVERCOMPLIANCE}

The stormy political climate of Title $\mathrm{V}$ implementation provides a unique setting in which to study regulatory overcompliance. Building on the history just outlined, in this section we will discuss the anecdotal evidence and theoretical foundations that support four hypothetical overcompliance determinants: a complying organization's internal control processes or red tape; its degree of experience with permit application processes; the quantity and quality of contacts with state regulators; and whether the company subcontracted its compliance-related activities. The anecdotal evidence derives from interviews that were conducted as background research for this project, and the supporting theories are pulled from a range of scholarship governing organization behavior. First, though, we will begin with a discussion of regulatory overcompliance.

\section{Title V and Overcompliance}

The environmental policy literature has historically assumed that companies will minimally comply with environmental regulations (Blinder 1987). Recent research has contradicted this assumption with the finding that many companies overcomply with pollution standards. While this overcompliance may be in conjunction with intraindustry agreements (Lyon and Maxwell 1999) or voluntary programs devised by regulators (Welch, Mazur, and Bretschneider 2000), companies have also been found to overcomply without such overt external influences (McClelland and Horowitz 1999). The response has been to hypothesize the benefits of overcompliance, including preempting or weakening future regulations (Arora and Cason 1995; Maxwell, Lyon, and Hackett 1998); avoiding the risk of closer surveillance (Harrington 1988); triggering tougher standards to disadvantage the competition (Barrett 1991; Salop and Scheffman 1983); enhancing corporate image in public reporting requirements (Arora and Gangopadhyay 1995); and increasing production efficiency (DeSimone and Popoff 1997; Schmidheiny 1992). McClelland and Horowitz (1999), in an attempt to explain why the pulp and paper firms they studied emitted below 50 percent of allowable levels, offer the additional possibility that plants compensate for uncertainties in production technologies and emissions. These hypotheses share the broader concept that overcompliance is a strategy to minimize uncertainty, to lessen regulatory interference, to lower competitiveness, to improve poor public image, or to offset current and future noncompliance. 
In the context of Title V, companies may overcomply with permit application requirements to minimize the probability that the highest corporate executive will be held criminally liable for submitting misleading permit information, via the CAAA's designated felon clause. Since the mid-1980s, environmental regulators have sought to raise the perceived risks of noncompliance-and thus motivate compliance-by criminalizing environmental violations (Heyes 1998). Because of this clause, dozens of corporate executives are tried each year and imprisoned for environmental damages (Heyes 1998, 9). While the number of convictions remains small, the intent is to generate a disproportionate fear that high-level employees can face a prison sentence for the failings of the firm. (Heyes 1998, 9). Thus the CAAA's designated felon clause seeks general deterrence that captures the attention of all violators (Reiss 1984; Scholz and Wei 1986). This strategy may lead many polluters to overestimate the probability of wrongful conviction and consequently to invest a higher level of effort in compliance (Heyes 1998).

Overcompliance with Title $\mathrm{V}$ permit application requirements is expected to generate excessive information and documentation that is meant to communicate to regulators conscientiousness, transparency, and trustworthiness. Herein lies one major difference between overperforming an environmental standard and overcomplying with environmental paperwork: the likelihood of the resulting environmental benefit. Under most (but not all) scenarios, emission reductions are anticipated from environmental overperformance. For example, some scholars theorize that firms will emit at levels below regulatory standards but above what is technically possible, in the hope of influencing regulators to preempt regulations (Maxwell et al. 1998) or to set lower future or pending standards than their potential performance (Lutz, Lyon, and Maxwell 1998). In contrast, overdocumenting environmental paperwork (such as the Title V permit application) does not automatically lead to emission reductions. This is not to dispute the possibility that excessive information can enhance source awareness of emissions or identify pollution prevention opportunities. However, the likelihood appears small that environmental information will lead to voluntary emission reductions in the absence of preexisting corporate motivation.

\section{ANECDOTAL EVIDENCE OF TITLE V COST DETERMINANTS}

The political turbulence surrounding Title $\mathrm{V}$ implementation contributed to a shifting regulatory landscape that in turn contributed to unintentional overcompliance (Bozeman and DeHart-Davis 1999). By the time EPA had released white papers

477/J-PART, October 2001 
softening its stance on documenting insignificant emission sources and requiring permit revisions for minor operational changes, many companies had already undertaken related work that would have been exempt under the new policies. For example, one permit engineer at a large Georgia chemical manufacturer reported spending half her time for several months documenting insignificant emission sources, time that could have been devoted to other tasks had the white papers been released earlier. ${ }^{4}$

In addition to federal backsliding on provisions of the original regulation, there is anecdotal evidence that confusion among state regulators over Title $\mathrm{V}$ requirements also contributed to overcompliance behaviors by leading complying companies to overdocument emissions information. At least one EPA official acknowledges this possibility, noting that "there has been great speculation among state regulators on the level of detail required, even though it should be clear that there is not a need to document every gram on every stack." The operations manager of a small label manufacturer noted: "We attended several statesponsored Title $V$ workshops, and with each session, the information changed." Perceptions of an unstable regulatory information environment may also have been exacerbated by high turnover rates among permit engineers, many of whom were hired specifically for Title $\mathrm{V}$ implementation only to be lured away by higher salaries in the private sector. ${ }^{6}$ As one chemical company engineer conveyed:

One of the difficulties in completing the application is that the compliance officer keeps changing. Replacements tend to be young, with little experience in the field. It's kind of sad when big brother comes to check on you and they're not capable of doing so.?

${ }^{4}$ Interview with operations engineer of a southeastern chemical firm, January 1996.

${ }^{5}$ Interview, May 1996.

${ }^{6}$ The Air Protection Bureau of the South Carolina Department of Health and Environmental Quality experienced particular problems retaining permit engineers, who were being lured by the larger salaries of consulting firms anticipating years of Title $\mathrm{V}$ work. Interview with assistant bureau chief, November 1996.

${ }^{7}$ Interview, January 1996.

${ }^{8}$ Interview with staff attorney in Environmental Protection Agency's Office of General Counsel, March 1996.
Perhaps the frustrations of obtaining compliance information led many companies -75 percent in the survey conducted for this research-to hire consultants to assist in the permit application process. The role of consultants in Title $\mathrm{V}$ permitting has been widely criticized by state and federal regulators, with the accusation that such firms use the designated felon effect to scare companies into overcompliance. A central Title $\mathrm{V}$ figure at EPA headquarters notes:

There often is a big difference between what Title $V$ costs and what it should cost. A lot of times I run into costs that companies have and I wish I could have talked to them first. They retain consultants and pay way too much money; if they talk to the right person on the state they can often do much better and can cost a phone call or price of paperwork. ${ }^{8}$

In fairness to consulting engineers who provide a reasonable scope of work on their clients' behalf, it is not certain that 
government officials such as this one are particularly well informed about appropriate scopes of work for Title V tasks. Furthermore, a philosophical objection to profiting from regulatory compliance may make some officials excessively pessimistic about the role of consultants. After all, if rampant overcompliance by consultants is truly the norm, the question is, Why do companies hire consultants at all for Title V work? Part of the answer may be the lack of in-house expertise to complete the permit application. This explanation jibes with the testimony of an environmental vice president for a major Atlanta printing manufacturer, whose company uses consultants only when inhouse staff lack the experience to perform a particular job. ${ }^{9}$ Competing organizational priorities may present an alternative explanation, one in which a company could have relevant expertise and still subcontract the job.

The informal evidence also suggests that companies using in-house resources to complete the Title $\mathrm{V}$ application are quite capable of overcomplying by themselves, with particular assistance from the designated felon clause. According to a seasoned engineering consultant, "Companies can create costs for themselves by overcomplying with the rules, out of fear of noncompliance." The experience of one Atlanta converting manufacturer supports this assertion. ${ }^{10}$ The firm's general manager, who was responsible for compiling the permit application, was driven by the fear that an innocent mistake in the permit application would send his company's president straight to jail. This fear was built, in part, by his predecessor's warning that Title $\mathrm{V}$ would be a paperwork nightmare with dire consequences for noncompliance. Accordingly, the manager estimated that he had spent half of his time on air-related monitoring and documentation activities during the year before the permit application was due.

\section{Theoretical Foundations of Title V Cost Determinants}

${ }^{9}$ Interview, January 1995.

${ }^{10}$ Interview with operations manager of small southeastern printing firm, May 1996.
The background interviews for this project suggest that regulatory uncertainty and perceived noncompliance risks were background factors in a company's decision to invest effort in the Title $\mathrm{V}$ permit application. The informal evidence is consistent with the notion that compliance is a calculated outcome (Stigler 1970) measurable on a continuous scale, with companies choosing higher or lower levels (Heyes 1998). In this section we will formalize the research hypotheses, using a range of theories to explicate permit application cost determinants.

Noncompliance Risks and Title V Permit Application Cost Determinants. Assuming that the CAAA's designated felon clause did indeed foster perceptions of high noncompliance risks, 
what factors increase the probability that companies will respond with overcompliance? One possibility is that overcompliance will be a function of an organization's internal process control systems and red tape. The organizational literature imparts the notion that companies use internal process control systems, defined as "carefully prescribed decisionmaking processes" (Ouchi 1977), to reduce risk. For years, red tape and other forms of bureaucratic pathology have been explained in terms of ineffective means of uncertainty reduction (e.g., Thompson 1961; Caiden 1991; Bozeman 2000). Further, diverse relationships between red tape and organization strategy have been documented in a variety of policy domains (Lan and Rainey 1992; Pandey and Bretschneider 1997), including environmental policy domains (Bozeman and DeHart-Davis 1999). Applying this notion to Title $\mathrm{V}$, we expect that companies with greater internal control and more red tape will overcomply.

Proposition 1. Companies with higher levels of internal control and red tape will be more likely to overcomply with their permit application requirements and thus have higher Title $\mathrm{V}$ costs.

This proposition views internal control systems as institutional responses to risk (Douglas 1985; Douglas and Wildavsky 1982), which use traditional procedures and routines to control uncertainty and ambiguity (Bozeman, Reed, and Scott 1992) and limit employee discretion (Wintrobe 1982). Organizations that emphasize adherence to process have been considered to have riskaverse cultures (Deal and Kennedy 1982; Bozeman and Kingsley 1998) that provide important guidelines for decision makers in uncertain situations (Douglas and Wildavsky 1982; Hofstede 1980.) Consequently, companies with higher levels of red tape are assumed to be inherently more risk averse than those with lower levels of red tape, and thus to respond to the Title $\mathrm{V}$ permit application process with a higher level of financial effort to minimize noncompliance.

The organizational literature also names problem domain familiarity as a key determinant in risk minimization strategy (Sitkin and Pablo 1992). Organizations tend to interpret new tasks using familiar problem categories (Cohen, March, and Olsen 1972; Dearborn and Simon 1958) or to apply preexisting approaches to current problems (Langer 1978; March and Simon 1958). Generalizing from past experience to present tasks can lead to positive outcomes, particularly when prior tasks have requirements that are similar to present ones (Hearst and Koresko 1968; Kamin 1969). Furthermore, individuals improve on various manual tasks through repetition (Thurstone 1919), a process of

480/J-PART, October 2001 
learning and experience that contributes to knowledge and continually improves performance (Dutton, Thomas, and Butler 1984; Lieberman 1987). Consequently, organizations with more permitting experience are expected to be less likely to overcomply because they have prior knowledge of similar permitting tasks to which they can appeal.

Proposition 2: Companies that perceive permit inexperience to have hindered their Title $\mathrm{V}$ permit application processes will be more likely to have overcomplied with their permit application requirements and thus will have higher Title $\mathrm{V}$ costs.

When there is no prior experience on which to base current task approaches, then cost savings yielded by tapping existing information fail to materialize and, in fact, additional resources may be required to obtain and apply new information (Mazur 1994). In contrast, when previously completed tasks are similar to presently required ones, past behaviors will likely be generalized to current situations (Pinder 1984): behaviors learned in past situations are applied to a variety of similar new situations, thus providing a ready made response and precluding unnecessary learning (Nye 1979).

Organization scholars have asserted that firms favor internal over external information sources (Aguilar 1967; Keegan 1974), particularly when the information is technical (Choudhury and Sampler 1997). Consequently, experience can be gained by separate members of an organization engaging in the same task and building concurrent knowledge (Klimecki and Lassleben 1998). This assumption is supported by the tendency for companies with regulated facilities in multiple states to attempt to coordinate permit activities. ${ }^{11}$

Proposition 3: Companies with Title $V$ facilities in other states will be less likely to have overcomplied with Title $V$ permit application requirements and thus will have lower permit application costs.

Companies with sister facilities in other states may share information on Title $\mathrm{V}$ problems, which allows them to leverage informational economies of scale and eliminate potential duplication in intelligence efforts (Gilad and Gilad 1986). This assertion jibes with the empirically supported tendency of organizations to divide knowledge over subunits (Cohen and Levinthal 1990).

"Interview with southeastern packaging firm's environmental manager, January 1995.
Regulatory Uncertainty and Title V Cost Determinants. Economists have predicted that regulatory uncertainty can influence corporate compliance effort, although they disagree on the 
direction of alteration. Some argue that regulatory uncertainty leads companies to minimally comply, leaving fat in the emissions budget for future regulatory trimming (Baumol and Oates 1988). Others argue that regulatory uncertainty motivates companies to overcomply in anticipation of tighter future regulations (Arora and Cason 1995) or in fear of unintentional noncompliance (Heyes 1998).

In the Title $\mathrm{V}$ context, regulatory uncertainty has literal meaning, with ambiguous and contradictory information emanating from both official and nonofficial sources. This leads to the hypothesis that companies pursuing richer information channels with state and federal regulators will have higher compliance costs from attempting to resolve information ambiguity. This assertion actually contradicts traditional notions of information richness, defined as the information carrying capacity of data (Daft and Lengel 1984). Face-to-face communication channels are the richest and are considered to offer the highest probability of resolving information ambiguity, albeit in small increments of information (Daft 1995). Impersonal documents, such as informational brochures, are considered lean, offering high quantities of information but slim prospects for resolving information ambiguity (Huber and Daft 1987). Notions of information richness and the potential for resolving uncertainty rest on the existence of clarifying information in the environment, an assumption that is contradicted by the Title $\mathrm{V}$ story and is criticized by scholars who argue for a stronger consideration of social context (Markus 1994). In contrast, Title $V$ implementation was marked by confusion among state regulators over the exact nature of Title $\mathrm{V}$ compliance, rendering the pursuit of rich communication channels a potential source of higher costs from the need to negotiate more ambiguous information, not less.

Proposition 4: Companies that gather compliance information through richer state regulatory information sources will be more likely to overcomply with their permit application requirements and thus will have higher Title $\mathrm{V}$ costs.

In addition to pursuing rich information channels, organizations operating in uncertain environments may pursue higher volumes of information to resolve uncertainty (Leifer and Huber 1977). Organization theorists call this activity boundary spanning, which generates data that is ultimately used to craft messages back to the environment (Daft 1995, 87). Although boundary spanning is generally expected to clarify ambiguity (At-Twaijri and Montanari 1987), this research argues that ambiguity may be compounded if the information environment itself is equivocal. 
Specifically, higher volumes of information may increase costs if the resulting information is contradictory or ambiguous.

Proposition 5: Companies that are in more frequent contact with state regulators will be more likely to overcomply with their permit application requirements and thus will have higher Title $\mathrm{V}$ costs.

Interactions between regulated enterprises and state regulators represent a third dimension of information gathering under regulatory uncertainty. The information gathering process typically requires organizations to interface with one another in a goal-directed fashion (Fahey and King 1977). Further, organizations that seek information expect to satisfy their quests, and thus they may be frustrated with information sources when such efforts fail. In the Title $\mathrm{V}$ context, ambiguous and conflicting compliance information may contribute to perceived intelligence failures, and increase the cost of interpreting compliance requirements.

Proposition 6: Companies that perceive interactions with state regulators to be a hindrance in the Title $\mathrm{V}$ permitting process will be more likely to overcomply with their permit application requirements and thus will have higher Title $V$ costs.

This hypothesis assumes that companies that perceive state regulators as hindrances do so from frustration with information ambiguity, which is supported by background interviews with Title V-compliant firms.

Subcontracting is a strategy that allows Title V firms to avoid direct negotiation of informational uncertainties. The typical rationale for eliciting third-party assistance is that the vendor has an advantage over the contracting organization with respect to the provision of information services, since the vendor reaps the benefits of scale and scope (Ghoshal and Westney 1991). While subcontracting Title V compliance requirements reduces firms' information acquisition needs, it creates a principal-agent relationship that may increase costs for firms (Eisenhardt 1989). Third-party agents that routinely perform tasks for a range of clients typically have more information about task requirements than their clients have, resulting in asymmetric information that can be used for shirking and distortion (Eggertsson 1990). Another aspect of the principal-agent relationship is opportunism (Fama 1980), or in the case of Title V, task routines that go beyond what is legally required for the client firm. 
Proposition 7: Companies that hire consultants to assist in developing their Title $\mathrm{V}$ permit application will be more likely to overcomply with their permit application requirements and thus will have higher Title $V$ costs.

The differing profit objectives of clients and vendors (Elitzure and Wensley 1999)-particularly vendors seeking billable hourscan lead companies that hire subcontractors to invest more money than is necessary in compliance. While economists would frown on this scenario as a suboptimal outcome for the firm, it is perfectly reasonable that third-party compliance and its attendant financial cost is well worth the benefit of reducing noncompliance risk. This notion jibes with evidence that companies subcontract to spread risk between parties, but it contradicts evidence that cost efficiency is the primary motivation for subcontracting (Benson and Ieronimo 1996; Lacity and Hirschheim 1993).

The scholarly literature on subcontracting behavior raises this alternative hypothesis: companies that subcontract Title $\mathrm{V}$ permit application requirements could incur lower costs for those tasks. External contractors are generally assumed to be more economical providers of standardized goods and services because they accommodate the demands of multiple clients for similar tasks and thus tap internal economies of scale (Ghoshal and Westney 1991). Furthermore, subcontractors that seek repeat work are expected to have strong incentives against overcharging and overwork (Richmond, Seidmann, and Whinston 1992). Finally, subcontracting firms can use consultants to avoid the significant cost of hiring new personnel, thereby offloading the risk of economic uncertainties (Elger and Smith 1994). While these are all plausible possibilities, the episodic nature of the Title $\mathrm{V}$ permit application requirements (an initial application process with renewal every five years) combined with the controversial role of consultants in the Title $V$ permit application process favor a hypothesis based in principal-agent theory.

\section{Data and Measures}

To test our hypotheses of Title V overcompliance, we use data collected from a cross-sectional mail survey of representatives from Title V-regulated firms in Georgia, Oregon, South Carolina, and Wisconsin. These states were chosen because a review of standard industrial classifications revealed that they were home to a mixture of industry types and sizes. A mail questionnaire to Georgia firms initiated the survey process, which enabled us to clarify ambiguous wording and eliminate questions with nonvariant responses. The final survey instrument entailed ten pages and twenty-eight questions, including queries on 
estimates of categories of Title V compliance costs, corporate information-gathering patterns, characteristics of internal compliance resources, and basic organizational information such as company size and average administrative processing times.

The air quality agencies in the four states provided the databases that comprised the sampling frame. Drawing random samples from Georgia, South Carolina, and Wisconsin, we verified addresses and contact information for selected companies. The random sampling process yielded 498 Georgia companies, 414 South Carolina companies, and 441 Wisconsin companies. Because Oregon has a small Title V-regulated community, 242 sources, all were sampled. One week before the first survey mailing we distributed to target firms an alert letter conveying the research goals and inviting survey participation. Nonrespondents were sent another survey package one month after the first mailing. One month after this second mailing, we sent the remaining nonrespondents a cover letter enabling them to decline participation by calling a member of the research team. They were also alerted that we would follow up by phone to encourage their participation. These telephone calls marked the end of the survey process.

We calculated response rates by dividing the number of completed surveys by the adjusted sample size, which excluded surveys returned because of incorrect addresses. Response rates by state were 31 percent (Wisconsin), 35 percent (Georgia), 40 percent (Oregon), and 43 percent (South Carolina). While this is a response rate somewhat below our initial aspirations it is consistent with other national administrative surveys, including the response rate for the National Administrative Studies Project (e.g., Bozeman and Kingsley 1998; Lan and Rainey 1992). Moreover, the questionnaire was administered at a time when many government agencies were seeking information from the regulated communities and, given constraints, the response rate could not have been greatly increased in the absence of enormous additional research resources.

The ideal test for nonresponse bias would have been to compare characteristics of the Title $\mathrm{V}$ sample with that of the Title $\mathrm{V}$ population. Unfortunately, population data do not exist. Further, available data-such as U.S. census data on manufacturing firmsinclude many small firms that are exempt from Title $\mathrm{V}$ regulations, rendering such data of limited comparability to the study sample. Given that nonresponse bias can adversely impact a study's external validity, we conducted a wave analysis instead to identify differences in early versus late responders to the survey. This exercise assumes that late responders are more like

485/J-PART, October 2001 
nonrespondents, and comparisons with early responders reveal potential nonresponse bias (Bozeman, Reed, and Scott 1992, 319). Considering only the top one-third and the bottom one-third of respondents ordered by date of survey receipt (on average, one year apart by state), the wave analysis of Title $\mathrm{V}$ data revealed no statistically significant differences between early and late responders for Title $V$ costs $(p<0.37)$, number of facility employees $(p<0.78)$, or 1995 sales $(p<0.63)$.

\section{Title V Overcompliance}

Because it is impossible to identify the minimum compliance requirements for a Title $\mathrm{V}$ permit application-states vary in their requirements and firms can have drastically different compliance requirements-overcompliance is indirectly measured using the total firm-level costs for developing the Title V permit application. This measure assumes that higher permit application costs equate to overcompliance, an assumption rendered plausible only by the inclusion of key variables, which we will discuss, that control for the most obvious rival explanations.

To estimate the total cost of applying for a Title $\mathrm{V}$ permit application, we summed up corporate cost estimates in these categories: hiring consultants, hiring administrative personnel, hiring scientific and technical personnel, diverting work activity, and changing administrative systems. ${ }^{12}$ The categories were identified by the pretest survey and during background interviews as capturing the bulk of corporate costs. Missing data were replaced with zeros, based on the assumption that to date no cost had been incurred for that cost category.

Since there was no possibility of surveying companies only at the completion of their Title $\mathrm{V}$ activities, companies were asked to estimate permitting costs to date. This approach risks an underestimation of total costs, given that missing data and zeros could eventually be replaced with expenses. However, all the companies included in this analysis had filed their Title $\mathrm{V}$ permit applications before the survey date. Assuming that the lion's share of application costs was incurred during the permit application process, the risk of significant underestimation appears small.

${ }^{12}$ The original survey question is listed in the appendix.
Title $\mathrm{V}$ permit application costs are exponentially distributed (exhibit 1 ). Consequently, the data features a concentration of firms with costs up to $\$ 25,000$, followed by rapidly declining numbers of firms with Title $V$ costs beyond that amount. Due to the data's skewness, the resulting cost variable has a mean of 
Exhibit 1

Distribution of Title V Costs

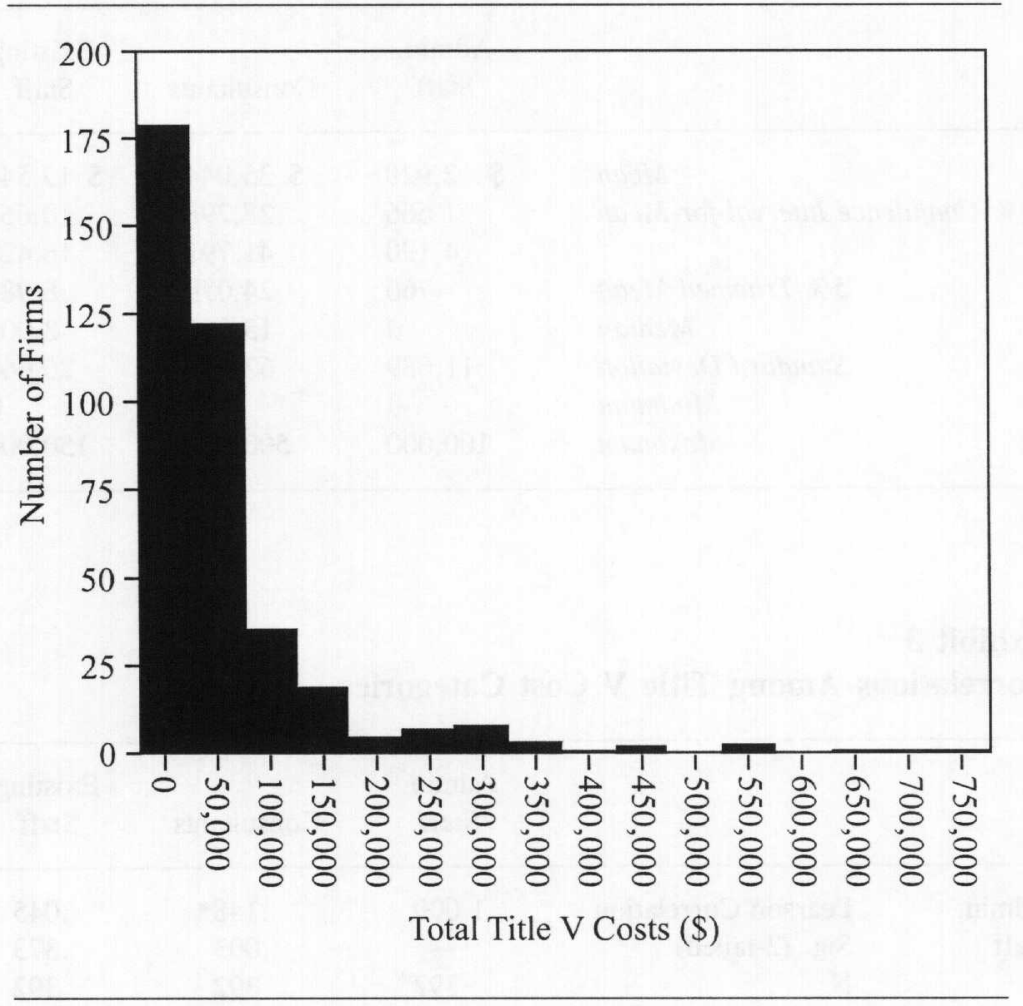

$\$ 62,067$, a 5 percent trimmed mean of $\$ 45,021$, and a median of $\$ 26,000$.

Exhibit 2 presents the mean of respondents' direct expenditures incurred for Title $\mathrm{V}$. The results indicate that the costliest item is hiring consultants (mean: $\$ 35,044$ ) and that the next major expense is diverting the work activity of existing personnel $(\$ 13,544)$. The hiring of new administrative $(\$ 2,928)$ and technical $(\$ 4,028)$ personnel is a relatively modest expense. The standard deviations of each cost category are large, indicating the skewness of the cost data and a wide divergence of permitting experiences and facility types.

Bivariate correlations between Title $\mathrm{V}$ cost categories reveal three significant relationships ( $\operatorname{sig}(\rho)<0.01)$ that support the validity of these cost measures (exhibit 3 ). The costs of administrative and technical personnel are significantly positively related $(\rho<0.46)$, suggesting that clerical workers were hired in support of technical permitting staff. Consulting costs are strongly positively correlated with administrative system upgrades $(\rho<0.39)$ 
Overcompliance in Air Quality Permitting

Exhibit 2

Descriptive Statistics for Individual Title V Cost Categories

\begin{tabular}{rrrrrr}
\hline & $\begin{array}{c}\text { Admin. } \\
\text { Staff }\end{array}$ & Consultants & $\begin{array}{c}\text { Existing } \\
\text { Staff }\end{array}$ & $\begin{array}{c}\text { Technical } \\
\text { Staff }\end{array}$ & $\begin{array}{r}\text { Admin. } \\
\text { Systems }\end{array}$ \\
\hline Mean & $\$ 2,928$ & $\$ 35,044$ & $\$ 13,544$ & $\$ 4,028$ & $\$ 7,818$ \\
95\% Confidence Interval for Mean & 1,666 & 28,298 & 10,666 & 2,160 & 4,837 \\
& 4,190 & 41,791 & 16,423 & 5,895 & 10,799 \\
$5 \%$ Trimmed Mean & 760 & 24,079 & 8,982 & 583 & 3,081 \\
Median & 0 & 15,000 & 3,000 & 0 & 0 \\
Standard Deviation & 11,689 & 62,489 & 26,660 & 17,299 & 27,610 \\
Minimum & 0 & 0 & 0 & 0 & 0 \\
Maximum & 100,000 & 500,000 & 150,000 & 160,000 & 250,000 \\
\hline
\end{tabular}

Exhibit 3

Correlations Among Title V Cost Categories

\begin{tabular}{|c|c|c|c|c|c|c|}
\hline & & $\begin{array}{l}\text { Admin. } \\
\text { Staff }\end{array}$ & Consultants & $\begin{array}{l}\text { Existing } \\
\text { Staff }\end{array}$ & $\begin{array}{c}\text { Technical } \\
\text { Staff }\end{array}$ & $\begin{array}{l}\text { Admin. } \\
\text { Systems }\end{array}$ \\
\hline $\begin{array}{l}\text { Admin. } \\
\text { Staff }\end{array}$ & $\begin{array}{l}\text { Pearson Correlation } \\
\text { Sig. (2-tailed) } \\
\text { N }\end{array}$ & $\begin{array}{c}1.000 \\
- \\
392\end{array}$ & $\begin{array}{l}.148^{*} \\
.003 \\
392\end{array}$ & $\begin{array}{l}.045 \\
.373 \\
392\end{array}$ & $\begin{array}{l}.459^{*} \\
.000 \\
392\end{array}$ & $\begin{array}{l}.256^{*} \\
.000 \\
392\end{array}$ \\
\hline Consultants & $\begin{array}{l}\text { Pearson Correlation } \\
\text { Sig. (2-tailed) } \\
\text { N }\end{array}$ & $\begin{array}{l}.148^{*} \\
.003 \\
392\end{array}$ & $\begin{array}{c}1.000 \\
- \\
392\end{array}$ & $\begin{array}{l}.372 * \\
.000 \\
392\end{array}$ & $\begin{array}{l}.160^{*} \\
.001 \\
392\end{array}$ & $\begin{array}{l}.390 * \\
.000 \\
392\end{array}$ \\
\hline $\begin{array}{l}\text { Existing } \\
\text { Staff }\end{array}$ & $\begin{array}{l}\text { Pearson Correlation } \\
\text { Sig. (2-tailed) } \\
\text { N }\end{array}$ & $\begin{array}{l}.045 \\
.373 \\
392\end{array}$ & $\begin{array}{l}.372 * \\
.000 \\
392\end{array}$ & $\frac{1.000}{392}$ & $\begin{array}{l}.206^{*} \\
.000 \\
392\end{array}$ & $\begin{array}{l}.307 * \\
.000 \\
392\end{array}$ \\
\hline $\begin{array}{l}\text { Technical } \\
\text { Staff }\end{array}$ & $\begin{array}{l}\text { Pearson Correlation } \\
\text { Sig. (2-tailed) } \\
\text { N }\end{array}$ & $\begin{array}{l}.459 * \\
.000 \\
392\end{array}$ & $\begin{array}{l}.160 * \\
.001 \\
392\end{array}$ & $\begin{array}{l}.206^{*} \\
.000 \\
392\end{array}$ & $\begin{array}{c}1.000 \\
\frac{-}{392}\end{array}$ & $\begin{array}{l}.220^{*} \\
.000 \\
392\end{array}$ \\
\hline $\begin{array}{l}\text { Admin. } \\
\text { Systems }\end{array}$ & $\begin{array}{l}\text { Pearson Correlation } \\
\text { Sig. (2-tailed) } \\
\text { N }\end{array}$ & $\begin{array}{l}.256^{*} \\
.000 \\
392\end{array}$ & $\begin{array}{l}.390 * \\
.000 \\
392\end{array}$ & $\begin{array}{l}.307 * \\
.000 \\
392\end{array}$ & $\begin{array}{l}.220^{*} \\
.000 \\
392\end{array}$ & $\begin{array}{c}1.000 \\
- \\
392\end{array}$ \\
\hline
\end{tabular}

488/J-PART, October 2001

Reproduced with permission of the copyright owner. Further reproduction prohibited without permission. 
and existing staff time $(\rho<0.37)$. These relationships suggest that the use of consultants does not involve total delegation; rather, it requires internal resources in support of its activities.

To verify the reliability of respondents' consulting cost estimates, we asked a second question in a separate section of the survey about the cost of hiring consultants. The Cronbach's Alpha between the separate consulting cost estimates is 0.97 , indicating acceptable internal consistency. The average difference in the estimates is $\$ 1,500$, with a 5 percent trimmed mean of $\$ 243$ and a median of zero. A t-test conducted on the paired variables indicates no statistically significant difference in the estimates $(p>.48)$.

To check the internal consistency with which companies estimate the costs of diverting work activity, a new variable was created that subtracted respondents' estimates of the internal personnel costs to work with only consultants from the cost of deploying existing personnel. Because the former variable is specific to outsourcing, it is reasonable to expect it to be a subset of the overall cost of diverting existing employees, and thus a dollar amount smaller than the general costs of diverting existing employees. Removing from consideration originally missing estimates, the average estimate for diverting existing employees toward general Title $\mathrm{V}$ activities is nearly $\$ 5,000$ higher than is the average cost of employees who work only with consultants. Furthermore, the two estimates are identical in 44 percent of the cases, indicating that for these companies internal costs were devoted entirely to supporting consultant activities.

To check the validity of the internal personnel cost measure, a new variable was created that divides the cost of existing staff time by the number of employees devoted to the Title $\mathrm{V}$ permit application. The resulting ratio assigns an average dollar amount to each employee diverted to work on Title V, indicating their degree of involvement in the permit application process. Examining only nonzero estimates of internal labor costs, the average cost per existing employee working on the Title $\mathrm{V}$ permit application is $\$ 5,166$, with a trimmed mean of $\$ 4,226$ and a median

${ }^{13}$ According to the Bureau of Labor Statistics in the U.S. Department of Labor, private industry employer compensation (including wages and benefits) averaged $\$ 19.85$ per hour worked. This figure combines blue and white collar workers, both of whom are anticipated to have participated in the Title $\mathrm{V}$ permit application process (March 2000). of $\$ 2,500$. The minimum cost per employee is $\$ 80$ and the maximum is $\$ 37,500$. Assuming an hourly cost of $\$ 20^{13}$ for the average employee involved in preparing the permit application, the result suggests that Title $\mathrm{V}$-dedicated employees have worked as little as four hours $(\$ 80 / \$ 20)$ or as much as twelve months $(37,500 / \$ 20 / 40$ hours per week $<47$ weeks), with an average time requirement of nearly six weeks. The upper range of these findings coincides with the high end of industry group estimates 
of six to twelve months for completing the average Title $\mathrm{V}$ permit application (Congressional Record 1990).

We made another external comparison of Title $V$ costs by extrapolating the total permit application costs reported in the survey to the population of 20,000 Title $\mathrm{V}$ facilities. This exercise yielded an estimated cost of $\$ 1.7$ billion dollars, which is only $\$ 300,000$ below industry estimates of such costs (Clean Air Implementation Project 1999, 7). This result, combined with the time estimates derived from existing staff costs, is consistent with recent findings that industry groups tend to overestimate aggregate regulatory costs (Harrington, Morganstern, and Nelson 2000).

\section{Organizational Control and Red Tape}

We measure internal control and red tape by summing the number of weeks required to obtain approval for seven standard administrative activities: hiring and firing employees, purchasing more and less expensive equipment, reorganizing departments, and initiating major and minor projects. ${ }^{14}$ While there are many possible constructions and measures of red tape (Bozeman 2000), the most common approach to measuring red tape among public administration scholars has been to examine the number of weeks required to perform core administrative tasks, either in absolute terms (e.g., Bozeman and Crow 1991; Bozeman, Reed, and Scott 1992) or in relation to a baseline such as the average for an industry (e.g., Bretschneider and Bozeman 1995; Pandey and Bretschneider 1997; Pandey 1995). This study conceptualizes organizational control and red tape in terms of the weeks required for core administrative tasks.

The approval times for purchasing low-cost equipment, firing and hiring, and initiating a minor project have mean values in roughly the same range (three to five weeks) and variances of a similar magnitude (exhibit 4 ). The clustering of these tasks may reflect more-frequent administrative events with shorter approval times and lower estimation error. In contrast, the higher means and standard errors of approval times for more-costly equipment purchases, departmental reorganization, and major project startups imply episodic events for which estimation is more difficult and consequently higher in error. Cronbach's Alpha for the individual red tape measures is 0.80 .

The mean approval times for a subset of administrative tasks-hiring and firing personnel and purchasing higher- and

${ }^{14}$ The original survey question is listed in the appendix. lower-cost equipment-are compared in exhibit 5 with those from a prior study's sample of research-oriented organizations in the

490/J-PART, October 2001 
Exhibit 4

Average Approval Time (Weeks)

for Red Tape-Relevant Activities

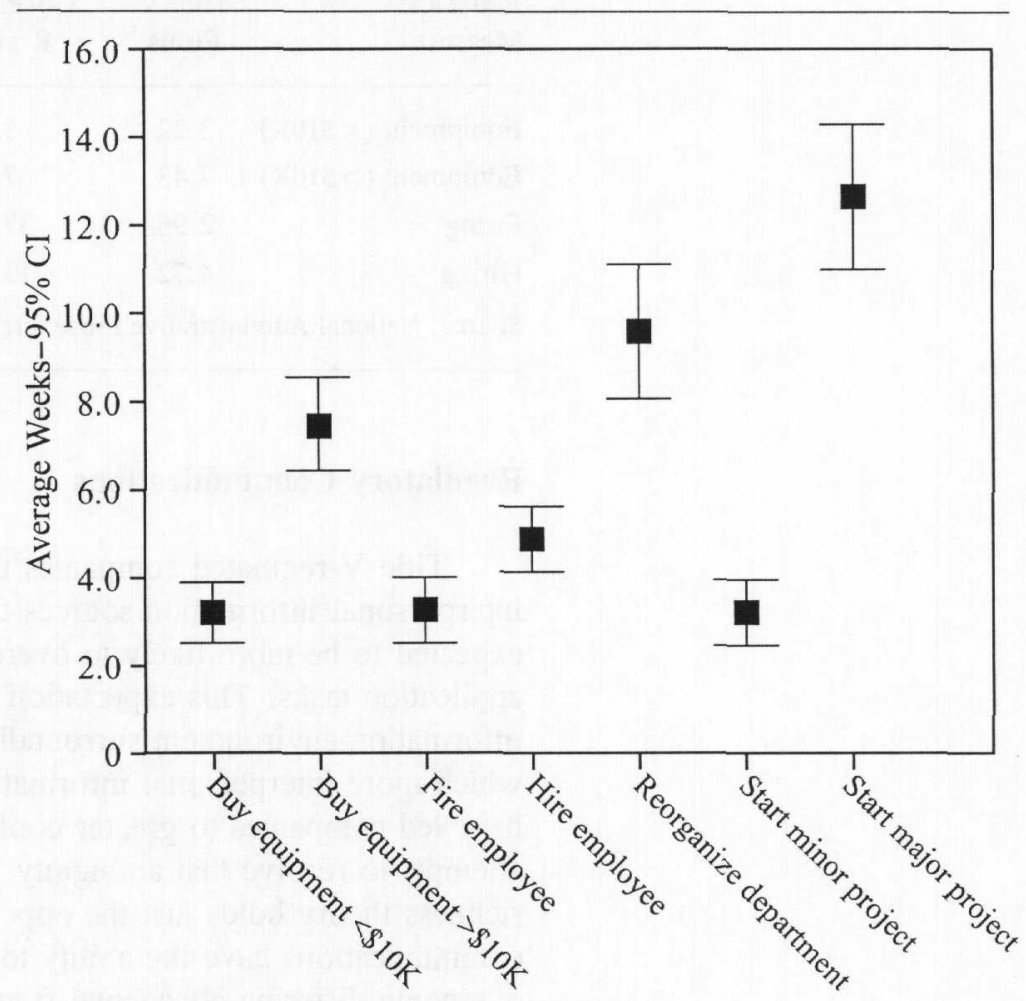

Administrative Tasks

public and private sectors (Bozeman et al. 1992). The Title V sample has a much lower average approval time for firing fulltime employees than do the government, industry, or university organizations in the study, possibly due to freedom from personnel constraints posed by government-funded research (Bretschneider and Bozeman 1995; Bozeman and Bretschneider 1994). Title V-regulated firms resemble the government organizations in approval times for low- and high-cost equipment purchases, with an average time nearly double that of industry and university research organizations. This result may be due to difference in the types of equipment purchased: capital expenditures by manufacturing firms may take longer to approve because they impact organizational productivity, whereas equipment purchases by university, government, or research-oriented private organizations may be more project specific and less relevant to key organizational functions. 
Exhibit 5

Comparing Red Tape Measures Across Sector

\begin{tabular}{lcccc}
\hline $\begin{array}{l}\text { Red Tape } \\
\text { Measure }\end{array}$ & $\begin{array}{c}\text { Title V } \\
\text { Firms }\end{array}$ & $\begin{array}{c}\text { Government } \\
\text { R and D }\end{array}$ & $\begin{array}{c}\text { Industry } \\
\text { R and D }\end{array}$ & $\begin{array}{c}\text { University } \\
\text { R and D }\end{array}$ \\
\hline Equipment $(<\$ 10 \mathrm{~K})$ & 3.22 & 3.08 & 1.28 & 1.32 \\
Equipment $(>\$ 10 \mathrm{~K})$ & 7.43 & 7.69 & 4.70 & 4.26 \\
Firing & 2.96 & 37.49 & 7.34 & 10.19 \\
Hiring & 4.72 & 13.37 & 3.85 & 6.14 \\
Source: National Administrative Procedures Project. & &
\end{tabular}

\section{Regulatory Communications}

Title V-regulated companies that pursue more-frequent and interpersonal information sources from state regulators were also expected to be more likely to overcomply with Title $\mathrm{V}$ permit application tasks. This expectation is based on the ambiguous information environment surrounding Title $\mathrm{V}$ implementation, in which more interpersonal information from state regulators may have led companies to greater confusion and higher costs from attempts to resolve that ambiguity. In contrast, traditional media richness theory holds just the opposite: more-interpersonal communications have the ability to change human understanding, overcome differing conceptual frames of reference, or clarify ambiguous issues in a timely manner (Daft and Lengel 1984 and 1986) than do less-interpersonal communications. Furthermore, tasks higher in equivocality (Daft and Trevino 1987, 357) or those that involve conflict of interest (McGrath and Hollingshead 1993) are held by the theory to require richer information media. Given that Title V permit application tasks were both equivocal and, for some firms, conflict ridden, it follows that firms would pursue richer communications.

The media characteristics that determine richness levels are: the opportunity for timely feedback; the ability to convey multiple cues; the tailoring of messages of personal circumstances; and the variety of language (Huber and Daft 1987, 152). These characteristics enable a hierarchy of traditional media in terms of information richness, including face-to-face contact, telephone conversations, personal written communications, formal written communications, and formal numeric communications (Daft and Lengel 1984). Thus a three-level ordinal measure sought to capture the richness of state-level Title $\mathrm{V}$ information sources. The resulting variable assigned companies a score of (3) if their 
information gathering efforts included attending meetings or workshops $(n=292)$, (2) if they included informally communicating with regulators $(n=87)$, (1) if they used printed materials only $(n=32)$, and $(0)$ if they gathered no Title $V$ information from the state agency $(\mathrm{n}=38){ }^{15}$

A second aspect of regulatory communications that was expected to influence Title $\mathrm{V}$ costs is the level of contacts between regulated firms and state air quality agencies regarding their Title $\mathrm{V}$ permits. ${ }^{16}$ These interactions can be classified as boundary spanning behavior, in which organizations gather information from their environments, among other reasons, to solve specific problems (El Sawy and Pauchant 1988; Cyert and March 1963; Fahey and King 1977). Furthermore, boundary spanning is expected to occur in more-uncertain environments (Leifer and Huber 1977; Duncan 1972). Consequently, Title V's ambiguous information environment is suspected of inflating Title $V$ costs by requiring companies engaged in more-intense boundary spanning activities to negotiate more equivocal information. Title $\mathrm{V}$ boundary spanning is measured by the sum of Title V-related contacts initiated by the state regulatory agency and the firm. Companies averaged eight contacts with regulators: states contacted companies on average six times, and companies contacted states on average ten times.

The final variable in this category of hypotheses reflects a respondent's perception (yes $=1$, no $=0$ ) that state regulators hindered the Title V permit application process. ${ }^{17}$ Perceptual variables have the advantage of providing a subjective assessment of more objective measures, and in some cases they have provided contradictory evidence (Bozeman and Kingsley 1998). The perception was that interactions with state regulators proved to be a Title $\mathrm{V}$ hindrance, intended to provide some measure of the outcome of higher or more interpersonal communications regarding permit application requirements. Eighty-seven percent of respondents $(n=421)$ did not perceive state regulators to be a hindrance in the Title $\mathrm{V}$ permit application process, whereas 13 percent did $(n=66)$.

${ }^{15}$ The original survey question is listed in the appendix. ${ }^{16}$ The original survey question is listed in
the appendix.

${ }^{17}$ The original survey question is listed in the appendix.

\section{Permitting Experience}

In contrast to the other hypotheses, firms more experienced with regulatory permitting are expected to have lower Title $\mathrm{V}$ compliance costs. Experience is defined as direct or indirect participation in events that contribute to an organization's knowledge stock regarding similar events (Dretske 1981). Organizational knowledge, in turn, increases an organization's capacity to 
absorb related knowledge and thus its informational economies of scale (Cohen and Levinthal 1990).

Two variables measure permitting experience related to Title $\mathrm{V}$. The first is a dummy variable that designates companies with Title $\mathrm{V}$ facilities in other states. ${ }^{18}$ The measure assumes that experience can be gained by separate members of an organization engaging in the same task and building concurrent knowledge (Klimecki and Lassleben 1998). This assumption is supported by the tendency for companies with regulated facilities in multiple states to attempt to coordinate permit activities. ${ }^{19}$ A little more than half ( 53 percent) of responding firms have Title $\mathrm{V}$ facilities in other states.

The second variable is also a dummy measure, delineating companies that perceive that their lack of permitting experience hindered the Title $\mathrm{V}$ permit application process. This provides a more direct measure-albeit a perceptual one-of the relationship between experience and the ease of completing the Title $V$ permit application. Twenty percent of companies $(n=92)$ perceived their own lack of permitting experience or technical capacity as hindrances in the Title $\mathrm{V}$ permit application process, whereas eighty percent did not $(n=357)$.

\section{Subcontracting}

Companies were expected to have higher Title $\mathrm{V}$ costs if they hired consultants to assist with permit application preparation. Delegating permit application tasks creates a principalagent relationship between the contracting firm and its delegatee (Jensen and Meckling 1986) that sets the stage for some divergence between subcontractor decisions and decisions that would maximize the contracting firm's welfare (Baiman 1982 and 1990; Gurbaxani and Whang 1991; Jensen and Meckling 1986). In the Title $\mathrm{V}$ setting, divergence of interests may include the quest for billable hours or standardized permit application routines that result in extraneous tasks (and thus costs) included in firms' permit application processes.

${ }^{18}$ The original survey question is listed in the appendix.

\footnotetext{
${ }^{19}$ Interview with environmental vice president of a major southeastern packaging manufacturer, April 1996.

${ }^{20}$ The original survey question is listed in the appendix.
}

Survey respondents were asked whether they used consultants to handle the entire permit application or only part of the permit application; nonrespondents to this question were assumed to have not hired a consultant. ${ }^{20}$ Seventy-five percent of respondents $(n=326)$ hired a consultant for some type of assistance, whereas 20 percent $(n=111)$ did not hire a consultant. Of the 75 percent that hired a consultant, 44 percent (142) elicited partial consultant support and 56 percent (184) contracted out for total 


\section{Overcompliance in Air Quality Permitting}

turnkey consulting support. Two dummy variables measure the three types of subcontracting support: full, partial, and none.

\section{Statistical Control Variables}

Basic variance in permitting cost may be attributable to company size, various characteristics of the home state, and the firm's emission characteristics. Six statistical controls were used to capture these influences, including four variables to measure environmental scale, one variable to measure facility size, and a set of dummy variables to determine the influences of the survey state.

Small manufacturers tend to have less-complex permit needs than do large manufacturers (Robinson 1999, 247). Furthermore, production scale is generally correlated with the size of on-site personnel (Chelius and Smith 1987, 193). To control for permit complexities attributable to manufacturing scale, the number of facility employees was included as a statistical control.

${ }^{21}$ Interview with Ollie Ficke, permit engineer consultant and project advisor, April 1996.

${ }^{22}$ Conversation with Michael O. Rodgers, principal research scientist with the School of Civil and Environmental Engineering at Georgia Institute of Technology, April 3, 2000.

${ }^{23}$ Companies in this data pursued either synthetic minor or major source permits. Synthetic minor sources by definition have lower emissions from legally enforceable restrictions on production that keep their emissions below Title $V$ triggering thresholds. Major sources have emissions above thresholds specified by pollutant and air quality of the facility location.

${ }^{24}$ When asked the reasonableness of this assertion, a senior industrial engineer with $\mathrm{CH} 2 \mathrm{MHill}$ noted: "All things being equal, this is probably a reasonably fair generalization. Emissions across media tend to be correlated. There are obviously many exceptions to this, but on average it should hold true." April 19, 2001.
Three dummy variables were used to represent the four states in which the surveys were administered: Georgia, South Carolina, Oregon, and Wisconsin. The inclusion of survey states in the model is meant to capture a range of unobservable influences (e.g., timing of permit applications, pre-Title $V$ operating permit program history, implementation resources, regulatory stringency) that defy a single classification.

Firm-level emission characteristics-while not necessarily linearly associated with permitting $\operatorname{costs}^{21}$-are nonetheless an obvious choice for statistical controls. Four measures were used to capture emission characteristics. Two dummy variables represented service providers, manufacturers, and raw materials producers, which were expected to capture escalating production volume and, by extension, emissions. ${ }^{22}$ Another dummy variable designated companies by permit type. ${ }^{23}$ The last two environmental variables were the natural logarithm of 1995 environmental regulatory costs and the number of employees who devoted at least half-time to environmental management. The latter variables assume that the scale of air quality emissions is probably not wholly unrelated to the amount of other types of environmental emissions (water, hazardous waste, etc.) ${ }^{24}$ and that specialized staff will be added in proportion to general environmental size (Robinson 1999). 


\section{ANALYSIS}

The study used an ordinary least squares (OLS) regression model to test the hypothetical determinants of Title $\mathrm{V}$ overcompliance. The OLS model explains 40 percent of the adjusted variance in Title $\mathrm{V}$ permit application costs (exhibit 6 ). The presence of Title $\mathrm{V}$ facilities in other states had a significant positive influence $(p<0.00)$ on permit application costs, running the opposite direction from what was hypothesized and incurring 55 percent higher permit application costs than single-site facilities. The number of company-agency contacts also had a significant positive influence $(\mathrm{p}<0.00)$, conforming with expectations and generating a 2 percent Title $V$ cost increase with each additional contact. The use of consultants for all permit application costs was a significant positive influence as expected $(p<0.02)$, resulting in 53 percent higher costs than that of facilities conducting Title $\mathrm{V}$ activities in-house. However, partial consultant usage was not significantly different from firms that used no consultant at all $(p<0.79)$. The remaining explanatory variables-red tape, inexperience, interpersonal information sources, and perceived agency hindrances-were insignificant cost determinants.

\section{Exhibit 6}

Modeling Title V Overcompliance

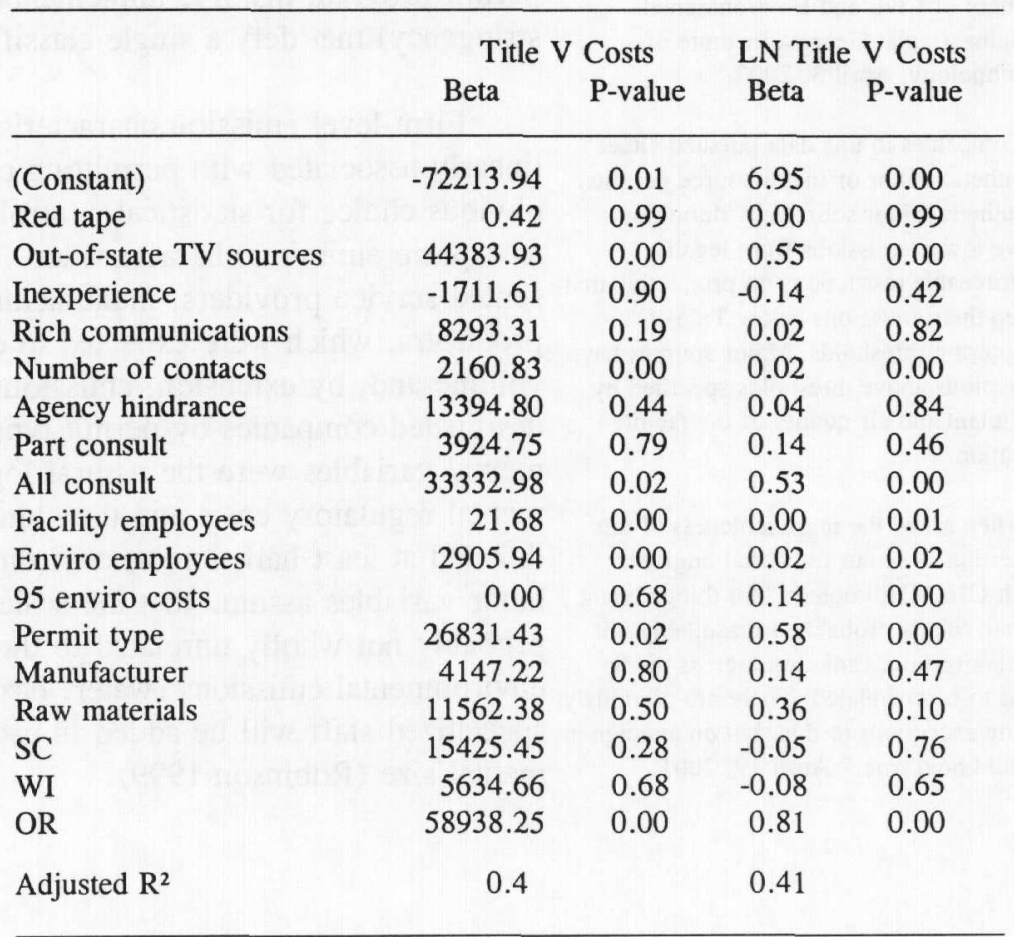

496/J-PART, October 2001 


\section{Overcompliance in Air Quality Permitting}

${ }^{25}$ In addition to transforming the dependent variable, the natural logarithm transformation was also applied to 1995 environmental costs, which have an intrinsically linear relationship to total Title $\mathrm{V}$ costs and are subject to the same scaling issues-large firms with large costs and small firms with small costs--as total Title $\mathrm{V}$ costs.

\footnotetext{
${ }^{26}$ It would be inappropriate to compare the explanatory powers of the original Title $\mathrm{V}$ cost model with its semilogarithmic sister because they feature different dependent variables. One alternative approach is to transform the predicted values of semilogarithmic models back to their original dollar increments (by raising e to those values as exponents) to generate a "pseudo-R2" value (Mendenhall and Sincich 1996, 226). The results of this exercise indicate that the semilogarithmic model explains 40 percent of the variance in Title V costs, as opposed to 39 percent of the variance explained by the original model.
}

\footnotetext{
${ }^{27}$ The variance inflation factor (VIF) method regresses each individual explanatory variable $\left(\mathrm{X}_{\mathrm{j}}\right)$ against the model's remaining predictor variables and extracts the coefficient of determination $\left(\mathrm{R}_{\mathrm{I}}{ }^{2}\right)$. The difference between 1 and the $R_{j}{ }^{2}$ is then inverted, so that highly correlated variables will have large VIF values from a small denominator and variables with low correlation will have a small VIF from a large denominator. While the rule-ofthumb VIF value indicating multicollinearity is ten (Neter, Kutner, Nachtsheim, and Wasserman 1996, 387), none of the individual variables have a VIF score over 2.3 .
}

With the exception of the dummy variable representing manufacturing firms, raw material producers, and South Carolina and Wisconsin responses, all control variables proved to be significant and positive: the number of facility employees $(p<.00)$, the number of environmental employees $(p<0.00)$, the type of permit sought $(p<0.02)$, and Oregon responses $(p<.00)$. Each additional facility employee is associated with a 0.01 percent increase in Title $V$ costs. Each additional environmental employee is associated with a 2 percent increase in Title $\mathrm{V}$ costs, whereas a 1 percent increase in 1995 environmental costs is associated with a 14 percent increase in Title V costs. Major source permits, required for larger emission sources, have nearly 60 percent higher emissions than synthetic minor permits, which are by definition below specific emission threshholds. And finally, Oregon facilities have 81 percent higher Title $V$ costs than Georgia facilities.

An examination of the original model's residuals revealed nonnormal and heteroskedastic distributions. To address these violations of the OLS assumptions, Title $\mathrm{V}$ permit application costs were transformed into a semilogarithmic form, which takes the natural logarithm of the dependent variable to stabilize the variance (Mendenhall and Sincich 1996, 397) and has the ancillary benefit of normalizing the residuals by eliminating their skewness (p. 411). ${ }^{25}$ The semilogarithmic Title V cost model yields normal and homoskedastic residuals and explains 41 percent of the variance (based on an adjusted $R^{2}$ ) in the transformed cost data. ${ }^{26}$ Individual variable performances change little, with two exceptions: The environmental regulatory cost variable and the dummy variable representing raw material producers both become significant Title $V$ cost determinants $(p<0.00$ and $\mathrm{p}<0.05$ for one-tailed tests, respectively).

Prior to running the semilogarithmic Title V cost model, we ran correlations among all the explanatory variables to detect any collinearity problems that might jeopardize the inferential capacity of the model coefficients. Collinearity was a particular concern, given that several model variables-particularly total environmental compliance cost and monthly permit hours-would logically be strongly correlated. These concerns proved to be unfounded, as the highest pair-wise correlation (between the number of facility and the number of environmental employees) was $\rho=0.24$. An additional diagnostic performed after running the regression model-specifically the variance inflation factorsuggested that collinearity among explanatory variables was not a problem. $^{27}$ 


\section{DISCUSSION}

An ordinary least squares regression (OLS) model of Title V permit application costs using internal corporate red tape, permitting experience, regulatory communications, and organizational scale variables explains 40 percent of the data's variance. This model also produced heteroskedastic and nonnormal residuals, leading to the generation of a semilogarithmic model that transformed the dependent cost variable by taking the natural logarithm of its individual values. The semilogarithmic model explains 41 percent of the adjusted variance in the transformed Title $V$ cost variable and, in addition, stabilizes the model residuals to meet OLS assumptions. Two separate diagnostic approaches suggested that multicollinearity was not a threat to the precision of the OLS estimators.

Corporate red tape is a highly insignificant influence on Title V permit application costs. The original hypothesis-that companies with higher internal red tape would invest more resources in permit application tasks to reduce noncompliance uncertainties-is unsubstantiated. There are several possible explanators for this result. First, approval times for administrative tasks may not measure red tape or corporate risk aversion, an explanation contradicted by the significant positive correlations demonstrated in previous studies between the red-tape measures and perceived red tape and organizational risk aversion (Bozeman and Kingsley 1998). Second, uncertainty reductions presumably sought by red tape may focus on internal organizational goals-stronger accountability of individual members (Clegg 1981) or explicit internal decision processes (Ouchi 1977)-as opposed to externally imposed goals, such as regulatory compliance. Thus companies with higher levels of red tape would be expected to have higher costs for internal financial audits or nonregulatory environmental management systems but not for federally required occupational safety record keeping. This alternative explanation is consistent with economic views of firm-level regulatory response as exercises in cost minimization, generally impervious to the effects of organizational structure (Blinder 1987).

The variables operationalizing regulatory communications produced mixed results. As we expected, the quantity of firmagency communications proved to be a significant positive influence on permit application costs, with each additional contact increasing Title $\mathrm{V}$ costs by 2 percent (exhibit 6 ). This result supports the notion that an ambiguous information environment increased permit application costs by requiring companies to negotiate conflicting data. However, several phenomena other 


\section{Overcompliance in Air Quality Permitting}

than information ambiguity may be driving the result. One possibility is that permit complexity drives both Title $\mathrm{V}$ costs and communication levels, resulting in a spurious relationship between the latter two. Permit complexity may encompass unresolved noncompliance issues or disputes over monitoring requirements that transcend systematic measures such as company size or industry segment. Another explanation shifts responsibility for compliance confusion from state regulators to the complying firms, who may be too incompetent, careless, or distracted by nonregulatory matters to adequately decipher permit application tasks. A final possibility is that intensive communication is a result of limited internal capacity that transcends company size or environmental staffing, where internal environmental resources are devoted to other regulatory matters and companies compensate by accelerating communications with regulators.

Firms that perceived that interactions with state regulators hindered their Title $\mathrm{V}$ process were expected to be frustrated primarily by ambiguous and conflicting Title $\mathrm{V}$ compliance information from state agencies. That such a perceived hindrance bore no relationship to Title $\mathrm{V}$ cost may indicate that aspects of regulator interactions not related directly to compliance costssuch as personality conflicts or a general resentment of regulators-contributed to the impediment. The null effect also negates the rival hypothesis that companies with more-costly permit application processes were simply irritated by Title V's resource requirements and thus were more likely to perceive hindrances from regulatory interactions.

Both permitting experience variables contradicted expectations. Perceived permit inexperience was an insignificant influence on cost, whereas the presence of Title $V$ facilities in other states was associated with 55 percent higher, rather than lower, permit application costs (exhibit 6). This result may be attributable to the complexities of coordinating permit applications across states: differences in state permitting requirements are a common frustration among regulated firms, particularly for companies with facilities in multiple states. ${ }^{28}$ While Title $V$ sought a standardized permitting approach across states, air quality agencies had considerable leeway in the details of permit application requirements (Kingsley, DeHart-Davis, and Bozeman 1998). Thus companies that attempt to coordinate Title $\mathrm{V}$ permit applications across multistate facilities may incur higher costs for streamlining diverse tasks. The implication for policy makers is

${ }^{28}$ Interview with environmental vice president of a major southeastern packaging manufacturer, April 1996. that Title $\mathrm{V}$ may have raised minimum standards for permitting requirements but failed to standardize those requirements across states, as intended.

499/J-PART, October 2001 
One explanation for the null relationship between perceived permit inexperience and permit application costs is that Title $\mathrm{V}$ instituted permit application requirements that were so different from those that previously were required by state agencies that permit inexperience was irrelevant to the process (i.e., every company was inexperienced in Title V). This possibility jibes with assertions of behavioral theorists that experience does not always yield positive returns (Nye 1979).

Companies that used consultants for all Title V tasks had 53 percent higher permit application costs than those that did not use consultants, a significant result in the direction predicted. However, companies that subcontracted only part of their Title V tasks did not have significantly different costs than those firms that used no consultant at all. Perhaps partial delegation mitigates expansive compliance by enabling subcontracting companies to retain sharper awareness of the scope of delegated tasks. This interpretation warrants caution, however. In the absence of a bigticket expenditure to reference, companies not using consultants may have underestimated internal costs because of failure to account for fringe benefits and overhead, which are built into consulting fees. To control for this possibility, we applied a fringe benefits multiplier of $1.30^{29}$ to the costs of new and existing staff working on Title $\mathrm{V}$ permit application tasks and regenerated the semilogarithmic model. The model's explanatory power decreases by 4 percent (to an adjusted $R^{2}$ of 0.36 ), while it produces only slight changes in the value or significance of the beta coefficients (exhibit 7). However, regenerating the model with an overhead multiplier of 2.0 applied to permit application costs eliminates the significance of full consulting services. ${ }^{30}$ The latter result fails to eliminate the possibility that companies

${ }^{29}$ Zweig and White Associates estimate the average fringe benefits multiplier for environmental consulting firms to be 1.30 (1999).

\footnotetext{
${ }^{30}$ At the suggestion of an anonymous referee, we ran a sensitivity analysis, building-in various overhead rates to survey respondents' Title V cost estimates. The range of overhead rates began at 2.0, with the intention of working up to the median overhead rate of 2.5 for architecture, engineering, and planning firms (Zweig and White 2000). Escalating the overhead rate proved unnecessary, as the differences between companies fully subcontracting and not subcontracting permit application costs disappeared at the 2.0 multiplier.
} without consulting assistance underestimated internal costs.

The dummy variable representing Oregon firms is highly significant and positive, indicating Title $V$ costs were 80 percent higher than those of Georgia firms. This finding is provoking, given that Oregon permit applications were due before the issuing of the first EPA White Paper, which reduced the requirement for documenting insignificant emission units to a checklist. (The remaining states had permit application deadlines well past the issuance of this white paper). The unfortunate timing of Oregon's deadline meant that sources that had taken the time to individually document insignificant emission units had wasted resources on a task that ultimately was not required (Inside EPA 1995). The Oregon result may be evidence of overcompliance due to a shifting regulatory landscape, or it could be a function of some other local characteristic not captured by the model's controls. 
Exhibit 7

Modeling Title V Overcompliance Using Fringe-Adjusted Personnel Costs

\begin{tabular}{|c|c|c|}
\hline & \multicolumn{2}{|c|}{ LN Title V Costs } \\
\hline & Beta & P-value \\
\hline (Constant) & 7.08 & 0.00 \\
\hline Red tape & 0.00 & 0.91 \\
\hline Out-of-state TV sources & 0.51 & 0.00 \\
\hline Inexperience & -0.15 & 0.37 \\
\hline Rich communications & 0.02 & 0.81 \\
\hline Number of contacts & 0.03 & 0.00 \\
\hline Agency hindrance & 0.01 & 0.98 \\
\hline Part consult & 0.02 & 0.91 \\
\hline All consult & 0.39 & 0.03 \\
\hline Facility employees & 0.00 & 0.00 \\
\hline Enviro employees & 0.02 & 0.02 \\
\hline 95 enviro costs & 0.15 & 0.00 \\
\hline Permit type & 0.57 & 0.00 \\
\hline Manufacturer & 0.15 & 0.46 \\
\hline Raw materials & 0.40 & 0.07 \\
\hline SC & -0.04 & 0.81 \\
\hline WI & -0.09 & 0.61 \\
\hline $\mathrm{OR}$ & 0.83 & 0.00 \\
\hline Adjusted $R^{2}$ & 0.36 & \\
\hline
\end{tabular}

A final implication of the research is that survey questionnaires can be used to elicit regulatory cost estimates. The method is not without its perils, as companies may exaggerate costs in an attempt to manipulate the regulatory process or may provide thoughtless answers in the haste to complete surveys. However, the existing evidence tends to contradict both possibilities.

Title V cost estimates generated from the survey are generally consistent with two separate industry group estimates. And while systematic upward biases in cost estimates are difficult to locate, data analysis reveals logical relationships (for example, between permit application costs and firm size) that support data validity. The risk of thoughtless estimation is mitigated, to a certain extent, by the high levels of internal consistency displayed by respondents in several cost categories. Available evidence thus supports the feasibility of using survey questionnaires to estimate regulatory costs, provided data analysis is accompanied by thorough scrutiny of the responses and cautious interpretation of the results. 


\section{CONCLUSIONS}

A skeptical reader may wonder just how it is possible to overcomply with environmental regulations. Arguably, since diminishing pollution is in the public interest, a company that chooses to exceed environmental requirements is simply a good corporate citizen. In the case of Title $\mathrm{V}$, at least, overcompliance does not necessarily equal good corporate citizenship; it can relate more closely to such factors as bad management and can generate excess cost to no desirable social end. This is not to say that improved facility information is an unworthy goal; after all, regulatory enforcement and compliance are weak in the absence of valid records. The larger question raised by Title $\mathrm{V}$ is how much additional information is necessary to improve enforcement and compliance. Quite possibly there are important thresholds of information needs, and effects may well diminish or even change in quality after those thresholds are met. Finally, even if all the additional information gathered in Title $\mathrm{V}$ lowered air pollution, economists (not to mention unemployed timber workers and fishermen) remind us that even the most noble environmental quality goals are not to be approached without limits. Environmental goals are easily cast in relief against social and economic goals.

For all these reasons, the notion of overcompliance is a useful research concept, even though it is a difficult one to measure. If companies are complying at highly different levels it is important to know the causes of those differing compliance rates, the information and communication needs associated with them, and (not addressed here) the possible implications for equity and a level playing field. Our results suggest that there is indeed reason to suspect overcompliance and that overcompliance is predictable. To some extent, and perhaps to no one's great surprise, the consultants' profit margins may well be a considerable transaction cost in regulating industry and a cause of a particular type of overcompliance.

What does one make of the finding that increased communication with state regulators leads to overcompliance? There is always the so-called IRS metaphor: people interact with state regulators at their peril. But it is much more likely that intensive communication is a result of either serious problems or limited internal capacity, or both. The state regulator seems to benefit little from increasing the hours and costs of complying, especially when the result is more data, not less pollution.

In sum, the very notion of overcompliance interjects some concern with balance. If it is possible to overcomply then it is also possible to undercomply. The regulators' mission is not 
maximum compliance; it is effective compliance. Studies of reasons for overcompliance, when set against studies of undercompliance and noncompliance, give the entire picture and, perhaps, a better basis for regulation.

\section{APPENDIX}

\section{QUESTIONNAIRE ITEM ON TITLE V COSTS}

[7] In considering your company's response to Title $\mathrm{V}$ permitting requirements, which type of costs-other than permitting fees-have you already incurred?

\section{Cost Category}

Hiring consultants for assistance in the application process

Hiring new administrative, accounting, or record-keeping personnel

Hiring new scientific and technical personnel to deal with the permit application process

Hiring new scientific and technical personnel to deal with pollution control requirements

Diverting work activity of existing personnel

Changing administrative systems (e.g., record keeping, filing,

management information systems, software)
Costs

$\$[$ COSTCON]

\$ [COSTADM]

$\$$ [COSTSCI]

$\$$ [COSTENV]

\$ [COSTDIV]

\$ [COSTSYS]

\section{RED TAPE QUESTION ITEMS}

[28] Please indicate, for each activity listed below, how much time (in weeks) is typically required between a request made by a unit within your company and the actual approval of the request. [Note: If no approval is necessary for the activity, write NA; if there is never a request for a particular activity, write NR.]

\section{Activity}

Hiring full-time employee

Firing full-time employee

Buying low cost equipment (under $\$ 10,000$ )

Buying more expensive equipment (over $\$ 10,000$ )

Reorganizing a department or unit

Starting a minor new project

Starting a major new project

\section{Weeks Required for Approval \\ [REQHIR] \\ [REQFIR] \\ [REQEQ1] \\ [REQEQ2] \\ [REQORG] \\ [REQPROJ1] \\ [REQPROJ2]}

\section{SURVEY QUESTION ON STATE AGENCY INFORMATION SOURCES}

[4] In gathering information about Title V permitting, which of the following sources of information has your company used? [Please check all that apply.]

$0=$ Not Checked; $1=$ Checked; No Missing Data

South Carolina Department of Health and Environmental Control

Informal communications with personnel [AGENINF1]

Meetings or workshops [AGENINF2]

Printed materials [AGENINF3]

Internet, website, or bulletin boards (WI) [AGENINF4]

appendix continues... 


\section{SURVEY QUESTION ON COMMUNICATIONS FREQUENCY WITH REGULATORS}

[9] Has your company been in communication (by letter, phone call, visit) with South Carolina Department of Health and Environmental Control (DHEC) officials about Title V? (If your company has not communicated with DHEC about Title V, please proceed to Question \#11.)

\section{[COM]}

$\square$ No $[=0]$

\section{Yes $\Downarrow[=1]$}

Company has contacted DHEC on different occasions. [COMTHEM]

DHEC has contacted us on different occasions. [COMUS]

\section{SURVEY QUESTION ON TITLE V HINDRANCES}

[8] Regardless of the stage of your company's Title $V$ activities, which factors (if any) have hindered your company's ability to meet its Title V permit application requirements? [Check all that apply.]

$0=$ Not Checked; $1=$ Checked, No Missing Data

High cost of activity required for Title V application [HINCOST]

Interactions with DHEC personnel [HINAGEN]

Company's limited knowledge of Title V procedures [HINKNWTV]

Our company personnel's limited technical knowledge [HINTECH]

Company's lack of previous permitting experience [HINEXPER]

Red tape at DHEC [HINSRED]

Red tape at USEPA [HINEPRED]

Red tape in this company [HINCRED]

$\square$ Lack of adequate company-level rules and procedures dealing with air emissions [HINLACK]

\section{SURVEY QUESTION ON OUT-OF-STATE TITLE V SOURCES}

[2] Does your company or parent company have sources that will need Title $V$ permits in other states? If so, how many facilities in how many states?

[OTHSOURC]

$\square$ No [ $=0]$

$\square$ Yes $\Downarrow[=1]$

\section{SURVEY QUESTIONS ON SUBCONTRACTING}

[14] The items in this question pertain to consultants. [If your company has not hired a consultant for help with its Title $V$ application, proceed to question 15.]

\section{[CONS]}

[a] In hiring a consultant to help with your company's Title V application, is the consultant

to provide turnkey services (to do the entire permit? [=2]

or,

to help with part of the permit? [=1]

$0=$ NO BOX CHECKED

[b] What was the total cost for consulting services? \$

[c] In some instances it is necessary for company employees to work with consultants. What is the estimated cost (if any) of your company's employees' work with consultants on Title V permit application activities? \$ [CONSCOMP] 


\section{Overcompliance in Air Quality Permitting}

\section{REFERENCES}

Aguilar, F.

1967 Scanning the Business Environment. New York: McGraw-Hill.

Arora, S., and Cason, T.

1995 "An Experiment in Voluntary Environmental Regulation: Participation in EPA's 33/50 Program." Journal of Environmental Economics and Management 28: 271-86.

Arora S., and Gangopadhyay, S.

1995 "Toward a Theoretical Model of Voluntary Overcompliance." Journal of Economic Behavior and Organization 28:3:289-309.

At-Twaijri, M., and Montanari, J.R.

1987 "The Impact of Context and Choice on the Boundary Spanning Process: An Empirical Extension." Human Relations 40:783-98.

Baiman, $\mathrm{S}$.

1982 "Agency Theory in Managerial Accounting: A Survey." Journal of Accounting Literature 1 : (spring):154-213.

1990 "Agency Theory in Managerial Accounting: A Second Look." Accounting, Organizations and Society 14:4:341-71.

Barrett, S.

1991 "Environmental Regulation for Competitive Advantage." Business Strategy Review (spring).

Baumol, W., and Oates, W.

1988 The Theory of Environmental Policy. Cambridge: Cambridge University Press.

Bellas, C., and Skourtos, M.

1996 "Environmental Regulation and Costs of Information: Some Indications from Greek Industry." Journal of Environmental Management 47:3:205-21.

Benson, J, and leronimo, N.

1996 "Outsourcing Decisions: Evidence from Australia-Based Enterprises." International Labour Review 135:1:59.
Blinder, A.S.

1987 Hard Heads, Soft Hearts. Reading, Mass.: Addison-Wesley.

Bozeman, B.

2000 Bureaucracy and Red Tape. Upper Saddle River, N.J.: Prentice-Hall.

Bozeman, B., and Bretschneider, S.

1994 “The 'Publicness Puzzle' in Organization Theory: A Test of Two Alternative Explanations of Differences Between Public and Private Organizations." Journal of Public Administration Research and Theory 4:197-223

Bozeman, B., and Crow, $M$

1991 "Red Tape and Technology Transfer in U.S. Government Laboratories." Journal of Technology Transfer 16:2:29-37.

Bozeman, B., and DeHart-Davis, L.

1999 "Red Tape and Clean Air: Title V Air Pollution Permitting Implementation as a Test Bed for Theory Development." Journal of Public Administration Research and Theory 9:1:14177.

Bozeman, B., and Kingsley, G.

1998 "Risk Culture in Public and Private Organizations." Public Administration Review 58:2:109-18.

Bozeman, B.; Reed, P.; and Scott, P. 1992 "Red Tape and Task Delays in Public and Private Organizations." Administration and Society 24:3:290-322.

Bretschneider, S., and Bozeman, B. 1995 "Measuring Red Tape: An Approach Based on a Theory of Administrative Delays." In A. Halachmi, ed. The Enduring Challenges of Public Management, pp. 81-116. San Francisco: Jossey-Bass.

Bryner, G.C.

1995 Blue Skies, Green Politics. Washington, D.C.: Congressional Quarterly.
Bureau of Labor Statistics.

2000 "Employer Costs for Employee Compensation." http:// stats.bls.gov/ecthome.htm, 29 June.

Caiden, G.

1991 "What Really Is Maladministration?" Public Administration Review 51:6:486-93.

Chelius, J.R., and Smith, R.S

1987 "Firm Size and Regulatory Compliance Costs: The Case of Workers Compensation Insurance." Journal of Policy Analy sis and Management 6:2:193206.

Choudhury, V., and Sampler, J.L.

1997 "Information Specificity and Environmental Scanning: An Economic Perspective." MIS Quarterly 21:1:25-53.

Clean Air Implementation Project.

1999 Getting the Title V Program on Track: Will EPA Make the Necessary Changes to Its Policies? First Annual Title $V$ Report.

Clegg, S.

1981 "Organization and Control." Administrative Science Quarterly 26:545-62

Cohen, $\mathrm{M}$.

1986 "The Costs and Benefits of Oil Spill Prevention and Performance." Journal of Environmental Economics and Management 13:167.

Cohen, M.D.; March, J.G.; and Olsen, J

1972 "A Garbage Can Model of Organizational Choice." Administrative Science Quarterly 17:1-25.

Cohen, W., and Levinthal, D. 1990 "Absorptive Capacity: A New Perspective on Learning and Innovation." Administrative Science Quarterly 35:128-52. 
Congressional Record.

1990 S3165, no. 101, March 26.

Cyert, R.M., and March, J.G.

1963 A Behavioral Theory of the Firm. Englewood Cliffs, N.J.: Prentice-Hall.

Daft, R.L.

1995 Organization Theory \& Design, 5th ed. St. Paul: West Publishing.

Daft, R.L., and Lengel, R.

1984 “Information Richness: A New Approach to Managerial Behavior and Organizational Design." In L.L. Cummings and B.M. Staw, eds. Research in Organizational Behavior, pp. 191-233. Homewood, Ill.: JAI Press.

1986 "Organizational Information Requirements, Media Richness and Structural Design." Management Science 32:5:554-71.

Daft, R.L., and Trevino, L.K.

1987 "Message Equivocality, Media Selection, and Manager Performance: Implications for Information Systems." MIS Quarterly 11:3:355-66.

Deal, T., and Kennedy, A.

1982 Corporate Cultures: The Rite and Rituals of Corporate Life. Reading, Mass : AddisonWesley.

Dearborn, D., and Simon, H.

1958 "Selective Perception: A Note on the Departmental Identification of Executives." Sociometry $21: 140-44$.

DeHart-Davis, L.

2000 "Environmental Permit Costs: The Roles of Red Tape, Communications, Experience and Subcontracting."

DeSimone, L., and Popoff, F.

1997 Eco-efficiency: The Business Link to Sustainable Development. Cambridge, Mass.: MIT Press.
Douglas, $\mathrm{M}$.

1985 Risk Acceptability According to the Social Sciences. New York: Russell Sage.

Douglas, M., and Wildavsky, A.

1982 Risk and Culture. Berkeley: University of California Press.

Dretske, F.

1981 Knowledge and the Flow of Information. Cambridge, Mass.: MIT Press.

Duncan, $\mathrm{R}$.

1972 "Characteristics of Organizational Environment and Percieved Environmental Uncertainty." Administrative Science Quarterly 17:313-27.

Dutton, J.M.; Thomas, A.; and Butler, J.E.

1984 "The History of Progress Functions as a Managerial Technology." Business History Review 58:204-33.

Eggertsson, $\mathbf{T}$.

1990 Economic Behavior and Institutions. Cambridge: Cambridge University Press.

Eisenhardt, $\mathrm{K}$.

1989 "Agency Theory: An Assessment and Review." Academy of Management Review 14:1:57-74.

El Sawy, O., and Pauchant, T.

1988 "Triggers, Templates and Twitches in the Tracking of Emerging Strategic Issues." Strategic Management Journal 9:5:455-73.

Elger, T., and Smith, C.

1994 “Global Japanization: Convergence Competition in the Organization of the Labour Process." In Elger and Smith, eds. Global Japanization: The Transnational Transformation of the Labour Process, pp. 31-59. Routledge: London.

Elitzure, R, and Wensley, A.

1999 "Using Game Theory to Analyze Complex Projects: The Case of
Information Systems Outsourcing Arrangements." International Journal of Industrial Engineering-Theory: Applications and Practice 6:2:141-50.

Fahey, L., and King, W.

1977 "Environmental Scanning in Corporate Planning." Business Horizons (Aug.):61-75.

Fama, E.

1980 "Agency Problems and the Theory of the Firm." Journal of Political Economy 88:288-307.

Federal Register.

1992 57:140:(July 21):32250.

Ghoshal, S., and Westney, D.

1991 "Organizing Competitor Analysis Systems." Strategic Management Journal 12:1:17-31.

Gilad, T., and Gilad, B.

1986 "Business Intelligence-The Quiet Revolution." Sloan Management Review (summer): 53-61.

Gurbaxani, V., and Whang, S.

1991 "The Impact of Information Systems on Organizations and Markets." Communications of the ACM 34:1:59-73.

Harrington, W.

1988 "Enforcement Leverage When Penalties are Restricted." Journal of Public Economics 37:229-53.

Harrington, W.; Morgenstern, R.; and Nelson, P.

2000 "On the Accuracy of Regulatory Cost Estimates." Journal of Policy Analysis and Management 19:2:297-322.

Harrison, K.

1999 "Talking with the Donkey: Cooperative Approaches to Environmental Protection." Journal of Industrial Ecology $2: 3: 51-72$.

Hearst, E., and Koresko, M.B.

1968 "Stimulus Generalization and Amount of Prior Training on 


\section{Overcompliance in Air Quality Permitting}

Variable-Interval Reinforcement." Journal of Comparative and Physiological Psychology 66:133-38.

Heyes, A.G.

1998 "Making Things Stick: Enforcement and Compliance." Oxford Review of Economic Policy 14:4:50-63.

Hofstede, G.

1980 Culture's Consequences: International Differences in WorkRelated Values. London: Sage.

Huber, G.P., and Daft, R.L.

1987 "The Information Environments of Organizations." In F. Jablin, M.L. Putnam, K.H. Roberts, and L.W. Porter, eds. Handbook of Organizational Communications: An Interdisciplinary Perspective. Newbury Park, Calif.: Sage.

Inside EPA.

1995 "Part 70 Reproposal 'White Paper' to Have Dramatic Impact on Oregon." Air Permit Report 3:1.

Jensen, M.C., and Meckling, W.J.

1986 "Theory of the Firm: Managerial Structure, Agency Costs and Ownership Structure." In J. Barney and W. Ouchi, eds. Organizational Economics, pp. 214-74. San Francisco: Jossey-Bass.

Kamin, L.J.

1969 "Predictability, Surprise, Attention and Conditioning." In B.A. Campbell and R.M. Church, eds. Punishment and Aversive Behavior, pp. 279-96. New York: Appleton-CenturyCrofts.

Keegan, W.J.

1974 "Multinational Scanning: A Study of Information Sources Utilized by Headquarters Executives in Multinational Companies." Administrative Science Quarterly 19:3:411-21.
Kingsley, G.; DeHart-Davis, L.; and Bozeman, B.

1998 Assessing Compliance Burden from Implementation of Title $V$ Permitting Rules and Regulations: Case Study Evidence. Georgia Institute of Technology Draft Report, 100.

Klimecki, R., and Lassleben, H.

1998 "Modes of Organizational Learning-Indications from an Empirical Study." Management Learning 29:4:405-30.

Lacity, M., and Hirschheim, R.

1993 Information Systems Outsourcing. West Sussex, England: Wiley.

Lan, Z., and Rainey, $\mathrm{H}$.

1992 "Goals, Rules and Effectiveness in Public, Private and Hybrid Organizations: More Evidence on Frequent Assertions about Differences." Journal of Public Administration Research and Theory 2:1:5-24.

Landy, M.K.; Roberts, M.J.; and Thomas, S.R.

1994 The Environmental Protection Agency: Asking the Wrong Questions from Nixon to Clinton. New York: Oxford University Press.

Langer, E.

1978 "Rethinking the Role of Thought in Social Interaction." In J. Harvey, ed. New Directions in Attribution Research, pp. 35-58. Hillsdale, N.J.: Erlbaum.

Leifer, R., and Huber, G.P.

1977 "Relations Among Perceived Environmental Uncertainty: Organizational Structure, and Boundary Spanning Behavior." Administrative Science Quarterly 22:235-47.

Lieberman, M.B.

1987 "The Learning Curve, Diffusion and Competitive Strategy." Strategic Management Journal 8:441-52.
Lutz, S.; Lyon, T.; and Maxwell, J.

1998 "Strategic Quality Choice with Minimum Quality Standards." London: Center for Economic Policy Research. Discussion paper \#1793.

Lyon, T.P., and Maxwell, J.W.

1999 “'Voluntary' Approaches to Environmental Regulation: A Survey." In M. Franzini and A. Nicita, eds. Environmental Economics: Past, Present and Future. Aldershot, England: Ashgate.

March, J., and Simon, $\mathrm{H}$.

1958 Organizations. New York: Wiley.

Markus, M.L.

1994 "Electronic Mail as the Medium of Managerial Choice." Organization Science 5:4:502-27.

Maxwell, J.; Lyon, T.; and Hackett, S. 1998 Self-Regulation and Social Welfare: The Political Economy of Corporate Environmentalism. Milan: Fondazione Eni Enrico Mattei.

Mazur, J.

1994 Learning and Behavior. Englewood Cliffs, N.J.: Prentice-Hall.

McClelland, J., and Horowitz, j.

1999 "The Costs of Water Pollution Regulation in the Pulp and Paper Industry." Land Economics $75: 2: 220-32$.

McGrath, J., and Hollingshead, A 1993 "Putting the Group Back in Group Support Systems." In L. Jessup and J. Valacich, eds. Group Support Systems: New Perspectives, pp. 78-96. New York: MacMillan.

Mendenhall, W., and Sincich, T. 1996 A Second Course in Statistics: Regression Analysis. Upper Saddle River, N.J.: PrenticeHall. 
Neter, J.; Kutner, M.; Nachtsheim, C.; and Wasserman, W.

1996 Applied Linear Statistical Models, 4 th ed. Times Mirror Higher Education Group.

Novello, D.; Hoffnagle, G.;

McCutchen, G.; and Weiss, $\mathrm{K}$.

1995 Clean Air Operating Permits: A Practical Guide. Pittsburgh: Air and Waste Management Association.

Nye, R.D.

1979 What is B.F. Skinner Really Saying? Englewood Cliffs, N.J.: Prentice-Hall.

Ouchi, W.G.

1977 "The Relationship Between Organizational Structure and Organization Control." Administrative Science Quarterly 22:(March):95-113.

Pandey, S.K.

1995 Managerial Perceptions of Red Tape. Ph.D. diss. Syracuse University.

Pandey, S., and Bretschneider, S.

1997 "The Impact of Red Tape's Administrative Delay on Public Organizations' Interest in New Information Technologies." Journal of Public Administration Research and Theory 7:1:11330.

Pinder, $\mathrm{C}$.

1984 Work Motivation: Theory, Issues and Applications. Glenview, Ill.: Scott, Foresman.

Reinhardt, F.

1999 "Market Failure and the Environmental Policies of Firms: Economic Rationales for 'Beyond Compliance' Behavior." Journal of Industrial Ecology $3: 1: 9-21$.
Reiss, A.J. Jr.

1984 "Selecting Strategies of Social Control over Organizational Life." In K. Hawkins and J.M. Thomas, eds. Enforcing Regulation, pp. 23-35. Boston: KluwerNijhoff.

Richmond, W.; Seidmann, B.A.; and Whinston, A.

1992 "Incomplete Contracting Issues in Information Systems Development Outsourcing." Decision Support Systems 8:459-77.

Robinson, $\mathrm{K}$.

1999 "One-Stop Permitting? A Critical Examination of State Environmental Permit Assistance Programs." Economic Development Quarterly 13:3:245-58.

Salop, S.C., and Scheffman, D.

1983 "Raising Rivals' Costs." AEA Papers and Proceedings 73:2: 267-71.

Schmidheiny, $S$.

1992 Changing Course. Cambridge, Mass.: MIT Press.

Scholz, J., and Wei, F.H.

1986 "Regulatory Enforcement in a Federalist System." American Political Science Review 80:1250-70.

Segerson, K., and Miceli, T.J.

1998 "Voluntary Environmental Agreements: Good or Bad News for Environmental Protection." Journal of Environmental Economics and Management 36:109-30.

Sitkin, S.B., and Pablo, A.L.

1992 "Reconceptualizing the Determinants of Risk Behavior," Academy of Management Review $17: 1: 9-38$
Stigler, G.J.

1970 "The Optimum Enforcement of Laws." Journal of Political Economy 78:3:526-36.

Thompson, V.

1961 Modern Organization. New York: Knopf.

Thurstone, L.

1919 "The Learning Curve Equation." Psychological Monographs 26:151.

U.S. Environmental Protection Agency.

1995 White Paper for Streamlined Development of Part 70 Permit Applications.

1996 White Paper \#2 for Improved Implementation of Part 70.

Welch, E.W.; Mazur, A.; and

Bretschneider, S.

2000 "Voluntary Behavior by Electric Utilities: Levels of Adoption and Contribution by the Climate Change Program to the Reduction of Carbon Dioxide." Journal of Policy Analysis and Management 19:3:407-25.

Wintrobe, R.

1982 "The Optimal Level of Bureaucratization Within a Firm." Canadian Journal of Economics 15:4:649-68.

Zweig and White Associates.

1999 Financial Performance Survey of Environmental Consulting Firms.

2000 Finance and Accounting Survey of Architecture, Engineering and Planning Firms. 